\title{
Use of the evapo-destillation of reverse flow to obtein new products derived from grape
}

\author{
Armando Kamal Neme ${ }^{1, a}$, Marcelo Murgo ${ }^{2}$, and David Cobos ${ }^{2}$ \\ ${ }^{1}$ Ampplia Consultora, 5500 M26-C27 Barrio Dalvian Mendoza, Argentina \\ ${ }^{2}$ Instituto Nacional de Vitivinicultura, 5500 San Martín 430 Mendoza, Argentina
}

\begin{abstract}
The aim of this communication is to show the advantages of the use of wine alcohol as a preservative of must and its recovery through a system of evapo-destillation of reverse flow. Currently, the industry uses sulfur dioxide in the conservation of musts destined for concentration. The problem about the use of sulfur dioxide in the conservation of musts is that not ensure an anti-fermentative stability whole, but mainly in that it is not recovered, thereby producing a consequent pollution. Moreover concentrated musts usually contain a small presence of ethanol from micro-fermentations.

At laboratory scale it was verified an excellent state of preservation of alcoholizated must, and all the alcohol used was recovered by distillation.

The proposed system achieved a high reduction of production costs which is demonstrated by simulation process software, where it can show the energy savings compared to the conventional process for the same volume and concentration of product obtained.

Another important advantage of this system is that higher alcohols and flavors would not be lost because is not necessary a desulfitation process, thus obtaining better quality products.
\end{abstract}

\section{Introduction}

This work is based on the patent: "Process and equipment for the production of concentrated fruit juice by evapo-destillation" of the Chem. Eng.. Armando Kamal Neme [1].

\subsection{Market situation of musts in Argentina, the agreement Mendoza-San Juan}

The Argentine provinces of Mendoza and San Juan, which produce over $90 \%$ of the grape production Argentina, annually fixed by agreement with the government a minimum percentage of grapes that must be spent on the production of musts, respct to the total grape entered to winery during the season. In Table 1 shown the percentages from the last years.

Moreover due to the crisis in wine consumption in recent years have fallen must exports. Fig. 1.

Also in Table 2 and in Fig. 2, it can be seen that practically between 50 and $70 \%$ of must concentrated have destination the exportation.

This situation cause annually a large amount of excess production of musts so as of wines.

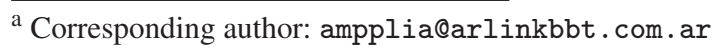

Table 1. Minimum percentage of grapes destined for the production of musts in Mendoza-San Juan agreements.

\begin{tabular}{|c|c|}
\hline Year & $\begin{array}{c}\text { Percentage of grape } \\
\text { from agreements } \\
\text { Mendoza-San Juan }\end{array}$ \\
\hline 2009 & $20 \%$ \\
\hline 2010 & $20 \%$ \\
\hline 2011 & $30 \%$ \\
\hline 2012 & $30 \%$ \\
\hline 2013 & $32 \%$ \\
\hline 2014 & $18 \%$ \\
\hline
\end{tabular}

\section{Argentinian exports of grape must concentrated}

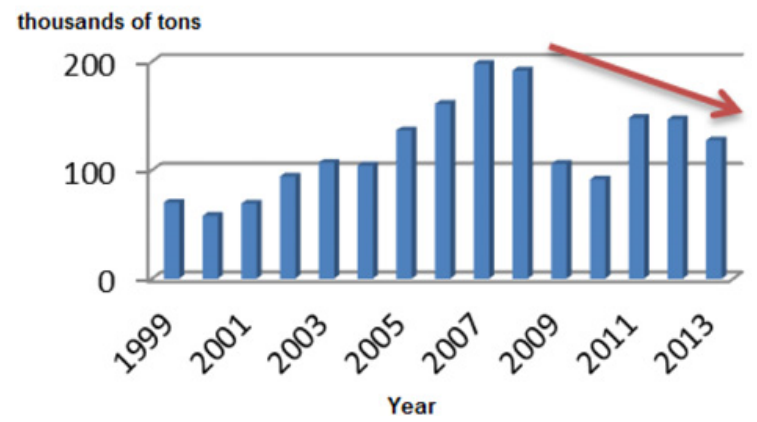

Figure 1. Argentine exports of grape must concentrated (GMC). 
Table 2. Production and Export. Of GMC in Argentina.

\begin{tabular}{|c|c|c|c|}
\hline Year & $\begin{array}{c}\text { Production } \\
\text { of GMC in } \\
\text { million } \\
\text { liters }\end{array}$ & $\begin{array}{c}\text { Exportation } \\
\text { of GCM in } \\
\text { millions } \\
\text { liters }\end{array}$ & $\begin{array}{c}\text { \% exported } \\
\text { compared } \\
\text { to } \\
\text { produced }\end{array}$ \\
\hline 2008 & 232 & 143 & 62 \\
\hline 2009 & 163 & 77 & 47 \\
\hline 2010 & 136 & 68 & 50 \\
\hline 2011 & 149 & 109 & 73 \\
\hline 2012 & 151 & 109 & 72 \\
\hline 2013 & 192 & 94 & 49 \\
\hline
\end{tabular}

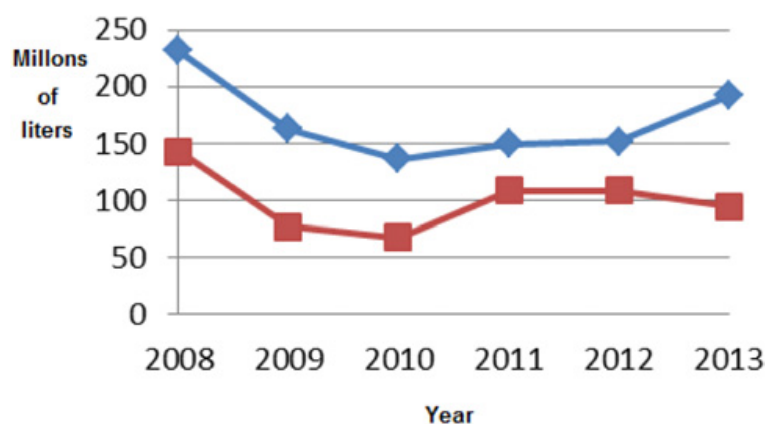

Figure 2. MCU production and exports in Argentina.

\subsection{Problems in the typical process of concentration of must in Argentina}

Harvested grapes must be processed in a very short time and also this concentrated has little stability.

That was the reason why the production of GMC must be based on the use of $\mathrm{SO}_{2}$ for its conservation. The dosage of sulfur dioxide for this purpose is of $2 \mathrm{~g} / \mathrm{L}$.

But sulfation of grape must and its conservation for an extended period not completely secures antifermentative stability and requires use of epoxy resins for pools currently questioned by possible generation of Phthalates.

Since desulfitation of must, which removes most of the $\mathrm{SO}_{2}$, but not all, is performed by stripping with water vapor in distillation columns, generally plates perforated, in counterflow between a descending flow of must and a water vapor upward, the alcohol and the aromatic substance or flavor precursors also volatile, are lost along with detached $\mathrm{SO}_{2}$ and water vapor used. The $\mathrm{SO}_{2}$ produces a consequent environmental pollution.

Furthermore, the musts concentrated usually contain a small presence of ethanol from microfermentations also lost by evaporation.

Also is important to note that in the usual process of concentration three thermal processes are performed: desulfitation, preconcentration and concentration, the last two are normally conducted in the same multiple-effect evaporator.

\section{Proposed system: Conservative alcohol and evapo-destillation}

To solve the problems outlined in the previous sections, the proposal is the use of wine alcohol of about $90 \% \mathrm{v} / \mathrm{v}$ as a preservative of musts that are destined for concentration, in

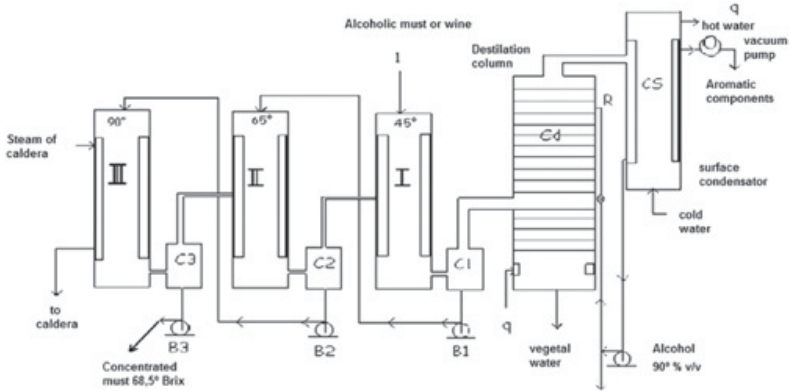

Figure 3. Evapo-destillation: Diagram of equipment and flows. References: q: heat; I-II and III: falling film evaporators; C1-C2C3: cyclone separator of vapors; B1-B2-B3: circulation pumps of must; A: reflux; Cd: distillation column.

the place of sulfation. This alcohol will be recovered and reused.

The alcoholization should be conducted at a concentration between 15 and $18 \%$ v/v.

Also is proposed for the concentration of alcoholized must implementing the "evapo-destillation" it was highly developed in Europe in the mid-twentieth century in the maize alcohol industry.

It consists in the use of an evaporator connected to a body of evaporators: the alcoholic must enter at the first stage of evaporation, where a gaseous fraction rich in alcohol goes to the distillation column to recover the wine alcohol (Fig. 3).

In the second and third effect the must is concentrated to reach $68.5^{\circ}$ Brix. The type of evaporators used would be falling film. Furthermore, these same units would be used for the concentration of wine in obtaining the wine alcohol necessary for alcoholizations.

The direction of flow would be reversed, that is, the liquid to evaporate and concentrate circulates in the opposite direction to the steam flow. This type of flow is used to process juices that containing aromatic components to be recovered and then reinstated the concentrated juice.

En este caso, el componente aromático, volátil, es el alcohol contenido en el vino o en el mosto alcoholizado.

In this case, the aromatic volatile component is the alcohol contained in the wine or alcoholic must.

\section{Tests on laboratory scale}

In these tests, sulfur dioxide is added to a fraction of must and wine alcohol to another fraction.

The addition of $\mathrm{SO}_{2}$ was $2150 \mathrm{mg} / \mathrm{l}$ and the alcoholic fraction was carried to $18 \% \mathrm{v} / \mathrm{v}$.

Determination of reducing sugars was performed, after dilution, by chemical method by titration with liquor Felling [8], with a tolerance of $\pm 7 \%$ [9]. Alcohol was analyzed by aerometric method [10] with a tolerance of \pm 0.3 [11]. The analytical technique used to determine the total sulfur dioxide was oxidation in acid medium $[4,6]$ with a tolerance of $\pm 35 \mathrm{mg} / \mathrm{l}$ [7].

As expected, the added alcohol insolubilizes largely of tartaric salts, forming a precipitate easy to separate from the liquid fraction. This property would enable to separate tartaric salts avoiding the cooling and destartarization 
Table 3. Variables entered and results.

\begin{tabular}{|c|c|c|c|}
\hline & \multicolumn{2}{|c|}{$\begin{array}{l}\text { Classic process of } \\
\text { concentration }\end{array}$} & $\begin{array}{c}\text { Evapo- } \\
\text { destillation }\end{array}$ \\
\hline \multirow[t]{2}{*}{ Base of calculation } & \multicolumn{2}{|c|}{$\begin{array}{c}5000 \mathrm{~kg} / \mathrm{h} \text { of sulphited } \\
\text { must }\end{array}$} & $\begin{array}{c}5930 \mathrm{~kg} / \mathrm{h}= \\
5000 \mathrm{~kg} / \mathrm{h} \\
\text { of must }+ \\
930 \mathrm{~kg} / \mathrm{h}\end{array}$ \\
\hline & $\begin{array}{l}\text { Precon- } \\
\text { centration. }\end{array}$ & $\begin{array}{l}\text { Concen- } \\
\text { tration. }\end{array}$ & \\
\hline Temp. $1^{\text {st }}$ effect $\left({ }^{\circ} \mathrm{C}\right)$ & 90,7 & 92,9 & 64,3 \\
\hline Pressure $1^{\text {st }}$ effect (bar) & 0,7 & 0,7 & 0,3 \\
\hline Temp. $2^{\text {nd }}$ effect $\left({ }^{\circ} \mathrm{C}\right)$ & 77 & 79,6 & 75,5 \\
\hline Pressure $2^{\text {nd }}$ effect (bar) & 0,4 & 0,4 & 0,4 \\
\hline Temp. $3^{\text {rd }}$ effect $\left({ }^{\circ} \mathrm{C}\right)$ & 71,1 & 74,4 & 95,8 \\
\hline Pressure $3^{\text {rd }}$ effect (bar) & 0,3 & 0,3 & 0,7 \\
\hline Concentrated must & \multicolumn{2}{|c|}{$1470 \mathrm{~kg} / \mathrm{h}$} & $1475 \mathrm{~kg} / \mathrm{h}$ \\
\hline $\begin{array}{c}\text { Final sugar } \\
\text { concnetration (weight } \\
\text { fraction) }\end{array}$ & \multicolumn{2}{|c|}{67,7} & 67,8 \\
\hline
\end{tabular}

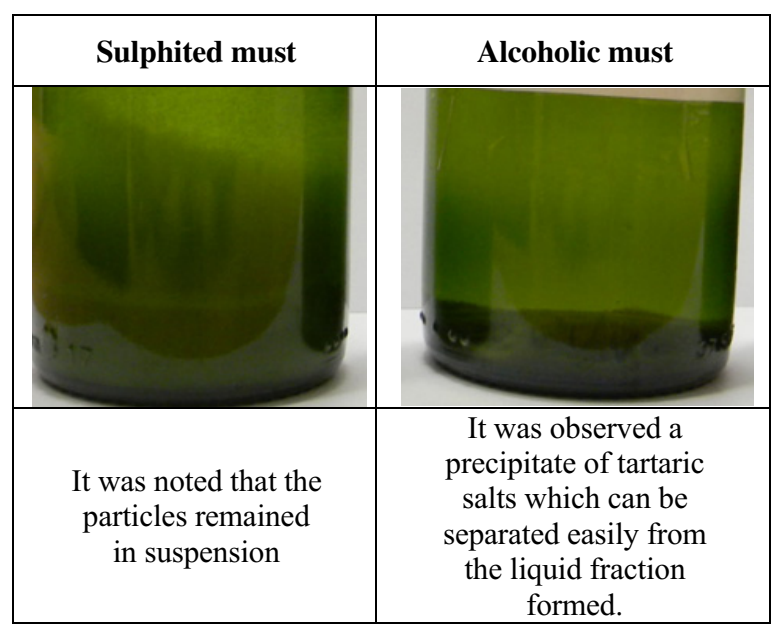

Figure 4. Observations in laboratory scale.

step carried out in the conventional concentration process (Fig. 4). Mosto Sulphiting Mosto Alcoholic

After 5 months it is proceeded to analyze the samples and the distilled alcohol recovery was $100 \%$.

As it was seen in Fig. 5, the result of alcoholization was very satisfactory, it evidenced that must sugar did not ferment and thus the alcoholization fulfilled the preservative function expected.

\section{Simulation}

The evapo-destillation of must alcoholized and the classic process of concentration practiced in Argentina for sulphited grape musts was simulated by the soft CHEMCAD 6, it was used typical values of this industry.

It was started with a base of calculation of $5000 \mathrm{~kg} / \mathrm{h}$ of must and for heating it was used steam at $100{ }^{\circ} \mathrm{C}$ and 1.013 bar.

The parameters that are taken to simulate and results can be seen in Figs. 4 and 5.

As shown in Table 5 the consumption of steam in the process of "evapo-destillation" was $20 \%$ less than

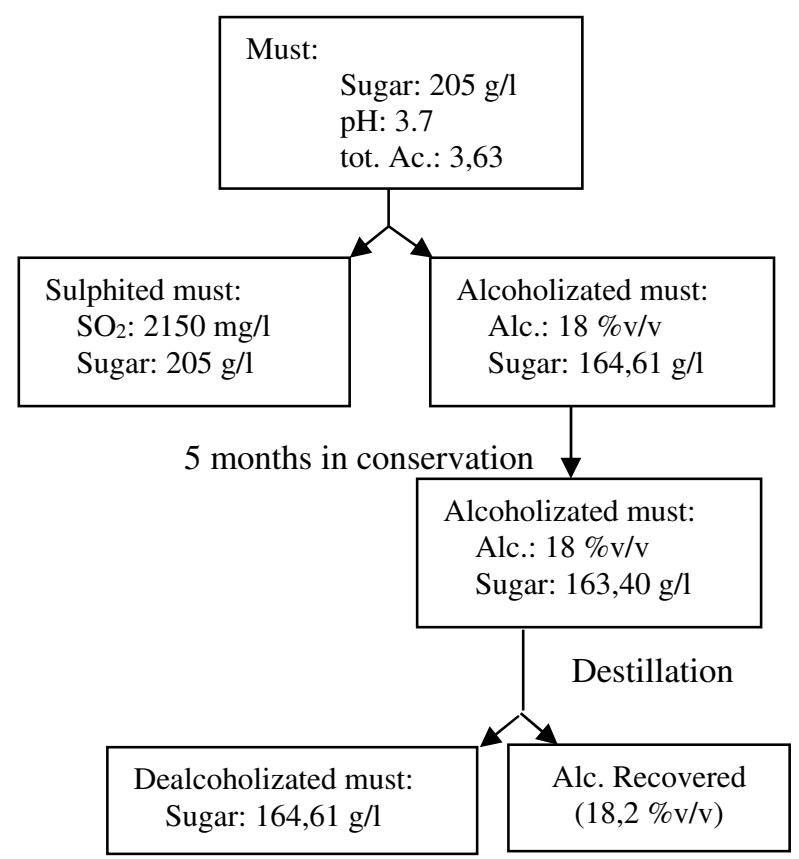

Figure 5. Schematic of laboratory-scale test.

typical method of concentration, with similar totals heat exchanged in the heating equipment, heat exchangers and evaporators, see Table 6 . It should be clarified that the current of concentrated must not was used to preheat the raw material in either of the two processes but the vegetable water of the base of distillation tower in evapodestillation process was used for this purpose. See Fig. 6 .

\section{Industrial scale}

Samples were taken before and after of a concentration by the typical system of must concentration in evaporator of five effect and the analytical data are shown in Table 7. 
Table 4. Variables Distillation Column.

\begin{tabular}{|c|c|}
\hline Number of plates & 12 \\
\hline Reflux in condenser & 4,5 \\
\hline Reflux in boiler & 0,3 \\
\hline Alimentation plates & $7,9 \mathrm{y} 11$ \\
\hline $\begin{array}{c}\text { Concentration of } \\
\text { vegetal water }\end{array}$ & $99,9 \% \mathrm{H}_{2} \mathrm{O}$ \\
\hline $\begin{array}{c}\text { Alcohol } \\
\text { concentration at the } \\
\text { top of the tower }\end{array}$ & $\begin{array}{c}92,6 \% \mathrm{v} / \mathrm{v} \text { of } \\
\text { wine alcohol }\end{array}$ \\
\hline
\end{tabular}

Table 5. Flow of caldera steam used in heat exchangers and evaporators.

\begin{tabular}{|c|c|c|c|}
\hline $\begin{array}{c}\text { Typical system of } \\
\text { concentration in } \\
\text { Argentina }\end{array}$ & $\mathbf{k g} / \mathbf{h}$ & $\begin{array}{c}\text { Evapo- } \\
\text { destillation }\end{array}$ & $\mathbf{k g} / \mathbf{h}$ \\
\hline $\begin{array}{c}\text { Preheater for } \\
\text { preconcentration }\end{array}$ & 500 & Preheater & 100 \\
\hline $\begin{array}{c}1^{\text {st }} \text { effect of } \\
\text { preconcentration }\end{array}$ & 1120 & $3^{\text {rd }}$ evaporator & 1510 \\
\hline $\begin{array}{c}\text { Preheater for } \\
\text { concentration }\end{array}$ & 60 & TOTAL & 1610 \\
\hline $\begin{array}{c}1^{\text {st }} \text { effect of } \\
\text { concentration }\end{array}$ & 320 & & \\
\hline TOTAL & 2000 & & \\
\hline
\end{tabular}

Table 6. Energy exchanged.

\begin{tabular}{|c|c|c|c|}
\hline $\begin{array}{l}\text { Typical system of } \\
\text { concentration in } \\
\text { Argentina }\end{array}$ & $\begin{array}{l}\text { thousand } \\
\mathrm{kcal} / \mathrm{h}\end{array}$ & $\begin{array}{c}\text { Evapo- } \\
\text { destillation }\end{array}$ & $\begin{array}{l}\text { thousand } \\
\text { kcal/h }\end{array}$ \\
\hline $\begin{array}{l}\text { Preheater for } \\
\text { preconcentration }\end{array}$ & 280 & Preheater & 5 \\
\hline Desulfitator & 9 & $\begin{array}{l}1^{\text {st }} \text { effect of } \\
\text { concentration }\end{array}$ & 710 \\
\hline $\begin{array}{c}1^{\text {st }} \text { effect of } \\
\text { preconcentration }\end{array}$ & 616 & $\begin{array}{l}2^{\text {nd }} \text { effect of } \\
\text { concentration }\end{array}$ & 773 \\
\hline $\begin{array}{l}2^{\text {nd }} \text { effect of } \\
\text { preconcentration }\end{array}$ & 516 & $\begin{array}{c}3^{\text {rd }} \text { effect of } \\
\text { concentration }\end{array}$ & 852 \\
\hline $\begin{array}{c}3^{\text {rd }} \text { effect of } \\
\text { preconcentration }\end{array}$ & 417 & TOTAL & 2340 \\
\hline $\begin{array}{l}\text { Preheater for } \\
\text { concentration }\end{array}$ & 28 & & \\
\hline $\begin{array}{l}1^{\text {st }} \text { effect of } \\
\text { concentration }\end{array}$ & 181 & & \\
\hline $\begin{array}{l}2^{\text {nd }} \text { effect of } \\
\text { concentration }\end{array}$ & 99 & & \\
\hline $\begin{array}{l}3^{\text {rd }} \text { effect of } \\
\text { concentration }\end{array}$ & 99 & & \\
\hline TOTAL & 2245 & & \\
\hline
\end{tabular}

Table 7. Analytical data of must sulfited and concentrated.

\begin{tabular}{|c|c|c|}
\hline & ${ }^{\circ}$ Brix & $\mathbf{~ m g / l ~ S O}$ \\
\hline Must sulfited & 20,6 & 2086 \\
\hline Preconcentrated & 40,5 & 41 \\
\hline Concentrated & 68,5 & 90 \\
\hline
\end{tabular}

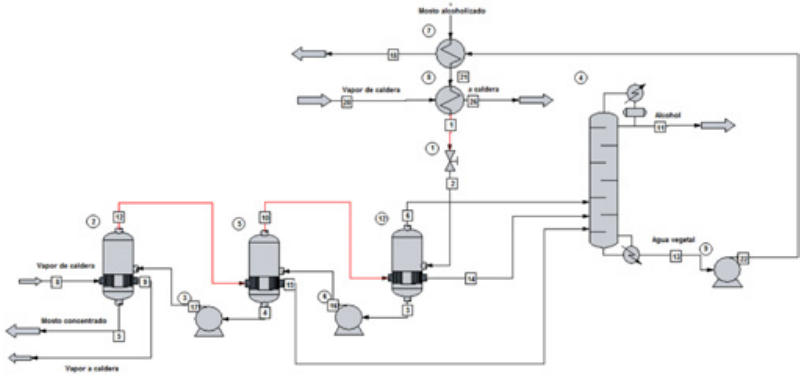

Figure 6. Evapo-destilation: flowsheet of simulation in CHEMCAD 6.

Table 8. Stages of "Concentration of must typical in Argentina" and "Alcoholization/Evapo-destillation".

\begin{tabular}{|c|c|c|}
\hline Stages & $\begin{array}{l}\text { Typical } \\
\text { concentration } \\
\text { process in } \\
\text { Argentina }\end{array}$ & $\begin{array}{c}\text { Alcoholization/Evapo } \\
\text {-destillation }\end{array}$ \\
\hline raw material & Sulfited Must & Fresh mosto \\
\hline Filtration & Filtration & $\begin{array}{l}\text { Centrifugation (or } \\
\text { other method of } \\
\text { rapid clarification) }\end{array}$ \\
\hline $\begin{array}{c}\text { Adjust } \\
\text { acidity / } \\
\text { Elimination } \\
\text { of salts }\end{array}$ & $\begin{array}{l}\text { Cation } \\
\text { exchange } \\
\text { (increased } \\
\text { acidity) }\end{array}$ & $\begin{array}{l}\text { Alcoholization. } \\
\text { Formation and } \\
\text { separation of } \\
\text { colloidal } \\
\text { sediments and } \\
\text { potassium tartrate. } \\
\text { Adjustment of } \\
\text { acidity }\end{array}$ \\
\hline Desulfitation & $\begin{array}{l}\text { Desulfitation } \\
\text { (sieve plate } \\
\text { columns of } \\
\text { perforated } \\
\text { plates, direct } \\
\text { steam } \\
\text { stripping) }\end{array}$ & \\
\hline Preconcent. & $\begin{array}{l}\text { Preconcent., } \\
45^{\circ} \text { Brix }\end{array}$ & \\
\hline Cooling & Cooling & $\longrightarrow$ \\
\hline Filtration & Filtration & $\longrightarrow$ \\
\hline Evaporation & $\begin{array}{c}\text { Reconcentra- } \\
\text { tion, } 68,5^{\circ} \\
\text { Brix } \\
\end{array}$ & $\begin{array}{l}\text { Concentración } \\
\text { direct to } 68,5^{\circ} \\
\text { Brix }\end{array}$ \\
\hline Filtration & Filtration & Filtración \\
\hline Packaging & Packaging & Packaging \\
\hline
\end{tabular}

Sugar determination was made by refractometer, while the analytical technique used to determine the total sulfur dioxide was oxidation in acid medium $[4,6]$ with a tolerance of $\pm 35 \mathrm{mg} / l$ [7].

The Table 7 shows that the grape juice concentrated has a remaining amount of $\mathrm{SO}_{2}$ that was not eliminated. It is important to note that still has not been done an industrial scale trial of alcoholization and evapo-destillation, but it is planned soon to perform in a plant in the east of Mendoza. 


\section{Conclusions}

\subsection{Advantages found if the proposed system is adopted}

- The must concentrated would be free of chemical preservatives, since ethanol used would be of the same origin.

- There would have no transfer of sulphite compounds to the environment, whereas that in desulfitation process, sulfur compounds are released into the atmosphere or solution.

- There would be no loss of higher alcohols and aromatics componets of the grapes for desulfitation. Using wine alcohol as a preservative, the volatiles would be condensed and reused together with the alcohol.

- In the case of concentrated wine, vinasse pollution is eliminated, getting a marketable wine extract.

- A single heat treatment increase performance by elimination of losses in the process of desulfitation process, double concentration and double filtration. See Table 6.

- Steam consumption 20\% less than the typical concentration system in Argentina.

- Can be stored in unlined pools.

- The product obtained by evapo-destillation is more natural, in this case well called juice, while today the term must is used, in the practice and in the wine legislation.

- Do not introduce mineral water.

- The reverse flow allows that most part of the concentration of salts (from wine) or sugars (from alcoholizated must) occurs in the hottest area of the evaporator, thereby the fouling by tartaric salts are reduced.

- It is obtained an alcohol unrectified but totally genuine and usable for conservation antifermentativa of musts. This wine alcohol $(90 \% \mathrm{v} / \mathrm{v})$ can be recycled.

- No presence of residual amounts of $\mathrm{SO}_{2}$ in the final product.

- The cost of production of wine alcohol is significantly lower than the wine alcohol $96^{\circ}$ GL rectified which currently is obtained from distilleries from wines.

- Losses of alcohol during storage and processing of alcoholizated musts are estimated between 5 to $7 \%$ of the alcohol used.

- At laboratory scale, with the alcoholization was observed the formation of a precipitate and a limpid liquid unlike of the sulfitation which remains a turbid must.

\subsection{Disadvantages of the proposed system}

- Initial inversion to generate the volume of alcohol required.
- Initial inversion for alcohol recovery equipment and storage tanks.

\subsection{Other consequences of the proposed system}

- It shall legislate on the destination and use of the "wine alcohol preservative", wine extract and vegetal water.

- Concentrating wine for the production of alcohol and generating a vinous extract of high commercial value; the application of this system would eliminate the problem from wine surplus that are produced every year in Argentina, revalued at the same time the price of the must as wine product.

We thank the following professionals for collaborate and provide information to this work: Ms. Carla Aruani, Ms. Raquel Gargantini from National Wine Institute and Mr. Ramón García from Guanacache S.A.

\section{References}

[1] A.K. Neme, Proceso y equipo para la elaboración de jugos concentrados de frutas por evapodestilación, Patente de invención en trámite ACTA P 060101448, Fecha presentación: 12 de Abril de 2006

[2] A.K. Neme, Process and equipment for the production of concentrated fruit juice by evapo-destillation, Invention Patent pending ACTA P 060101448, Date Submitted: April 12, 2006

[3] A. Avalo, A. Varela, Modelling and simulation of a triple effect evaporator for the concentration of natural juices. Revista técnica de la Facultad de Ingeniería Universidad Zulia v.31 n.2. ISSN 02540770 (2008)

[4] B. Avalo, S. Pérez y M. Tovar. Caracterización preliminar del proceso de concentración del jugo natural de naranja en un evaporador de tres efectos. INCI v.34 n.11. ISSN 0378-1844. (Nov. 2009)

[5] J. Ribéreau-Gayon, E. Peynaud, P.Sudrau, P. ribéreau-Gayon, Tratado de Enología, Ciencias y Técnicas del vino (1980)

[6] R.P. Bates, J.R. Morris and P.G. Crandall. Principles and practices of small - and medium - scale fruit juice processing. Chapter 8. Juice stabilization and preservation. ISBN 92-5-104661-1 (2001)

[7] Resolution I.N.V. $\mathrm{N}^{\circ} \mathrm{C}-227 / 91$

[8] Resolution I.N.V. N ${ }^{\circ}$ C-143/94

[9] Resolution mayo de 1938 - Dirección Nacional de Química de la República Argentina

[10] Resolution $N^{\circ} 1165 / 83$

[11] Resolution INV N $123 / 85$

[12] Resolution $\mathrm{N}^{\circ} \mathrm{C}-41 / 91$ 